ICOSITER 2018 Proceeding

Journal of Science and Applicative Technology

\title{
ANALYSIS OF SHORELINE CHANGES ON KRUI BAY, WEST COAST OF LAMPUNG PROVINCE
}

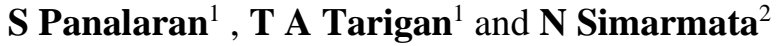 \\ ${ }^{1}$ Ocean Engineering, Institut Teknologi Sumatera \\ ${ }^{2}$ Geomatics Engineering, Institut Teknologi Sumatera
}

\begin{abstract}
Shoreline change is a natural process caused by the transported sediment generated by nearshore current to preserve the mass rates. Shoreline change can be a shoreline loss called abrasion as well as shoreline expansion due to sedimentation called accretion. Abrasion and accretion phenomenon can be regarded as a threat if they cause damage or potentially disrupts human activity. Identification of land use as well as geographical and physical condition of a region can be approached by satellite image analysis. This research uses Landsat Satellite imagery to observe shoreline changes based on the position of shoreline recorded through satellite images of 2004, 2010, and 2016. The image of one period overlapped with other period images is used to calculate the increment or decrease of shoreline occurring at a particular location. The results of this study will show the trend of increasing or decreasing the shoreline based on certain time and position
\end{abstract}

\section{Introduction}

Abrasion and sedimentation are natural processes of the coast due to sediment transported by nearshore currents. Coastal sediment transport occurs because of bottom shear stress which makes sediment at the bottom moving and transported. Abrasion and erosion yield shoreline change towards the sea or land.

One approach monitoring of shoreline change is through satellite imagery. The advantage of this method is less expensive but able to capture a large area over time. Analysis of shoreline changes with satellite imagery can be an initial process in determining strategic steps in coastal management. Accuracy in analyzing shoreline change is limited by spatial, temporal, and spectral resolutions. Accuracy of defining geographical coordinates is principal matter in measuring the position of the shoreline. The accuracy is attempted by rectifying the satellite imagery based on corrected coordinates obtained from reference imagery (raster data) or map (vector data). 
ICOSITER 2018 Proceeding

Journal of Science and Applicative Technology

\section{Utilization of Landsat Imagery for Shoreline Change Study}

The definition of coastal is a land area that is directly adjacent with the sea and gets influenced by the sea such as wind, waves, and tides. The shoreline is the imaginary line as boundary between land and sea when the highest tide reaches the land (Tarigan, 2007). The land area mentioned before is an area above the water level which can be in the form of land, sand, rocks, and vegetation (Kasim, 2012).

Analysis of shoreline changes is obtained from topography measurements captured through satellite imagery several times. The principle of satellite technology is to capture the emission of electromagnetic waves emitted by objects on the earth's surface in various wavelength ranges (Suwargana, 2013). One of the satellites that are widely used to identify the earth object surface is Landsat-7 ETM+ Satellite. Landsat Satellite images can be downloaded free of charge at the web address http://earthexplorer.usgs.gov/. Landsat-7 ETM+ imagery has a spatial resolution of $30 \times 30$ meters and captures the earth's surface every 16 days. Landsat-7 ETM+ image have 8 bands (channels) for capturing electromagnetic waves through visible light and infrared waves. Infrared band (band-5) on ETM+ sensor is useful for identifying land and water boundaries. Water has a reflectance value almost equal to zero, meanwhile land has a reflectance value greater than zero at the wavelength of infrared. Absorption of infrared waves by water and reflectance from land produces contrasting colors to identify the boundaries between land and water (Kasim, 2012). Identification of shoreline has variety of methods, one of which is through multiband composites (Winarso et. Al, 2001). The principle of multiband composites is incorporation of several bands to highlight the physical characteristics of an earth's surface. Band combinations that are often used for identification boundaries between land and water, among others, are a combination of band 452, band combination of 147, band combination of 457, and band combination of 321 .

\section{Research Method}

Teh position of shoreline is obtained from the corrected position on Landsat-7 ETM+ satellite imagery. The initial process in analyzing satellite imagery is preceded by radiometric correction and geometeric correction. Radiometric correction is the process of cleaning noise in images caused by the process of scattering and reflecting electromagnetic waves in the air. Radiometric correction is applied by the histogram adjustment method based on the method from Mather (1987, in Tarigan 2007). Geometric correction is implemented on all satellite imagery by rectifying the natural appearance such as shoreline morphology and watershed, all of which refer to their base maps (issued by Badan Informasi Geospasial). 
ICOSITER 2018 Proceeding Journal of Science and Applicative Technology

Interpretation errors between satellite imagery and base maps are minimized by rectifying satellite image with one of the images which is considered to be a reference image. Shoreline identification must be attempted accurately to minimize measurement errors of shoreline changes by the human interpretation. Shoreline identification is carried out using the 4-5-2 band combined method to reinforce the boundary between water and land (Tarigan, 2007). Figure 1 is the result of pre-processing with 4-5-2 multiband combination. Shoreline changes can be investigated by arranging shoreline digitization results in the first year (2004) and subsequent years (2010 and 2016). Overlapping shoreline at certain time series (Figure 2) makes observers easily pay attention to the process of changing shoreline over time.

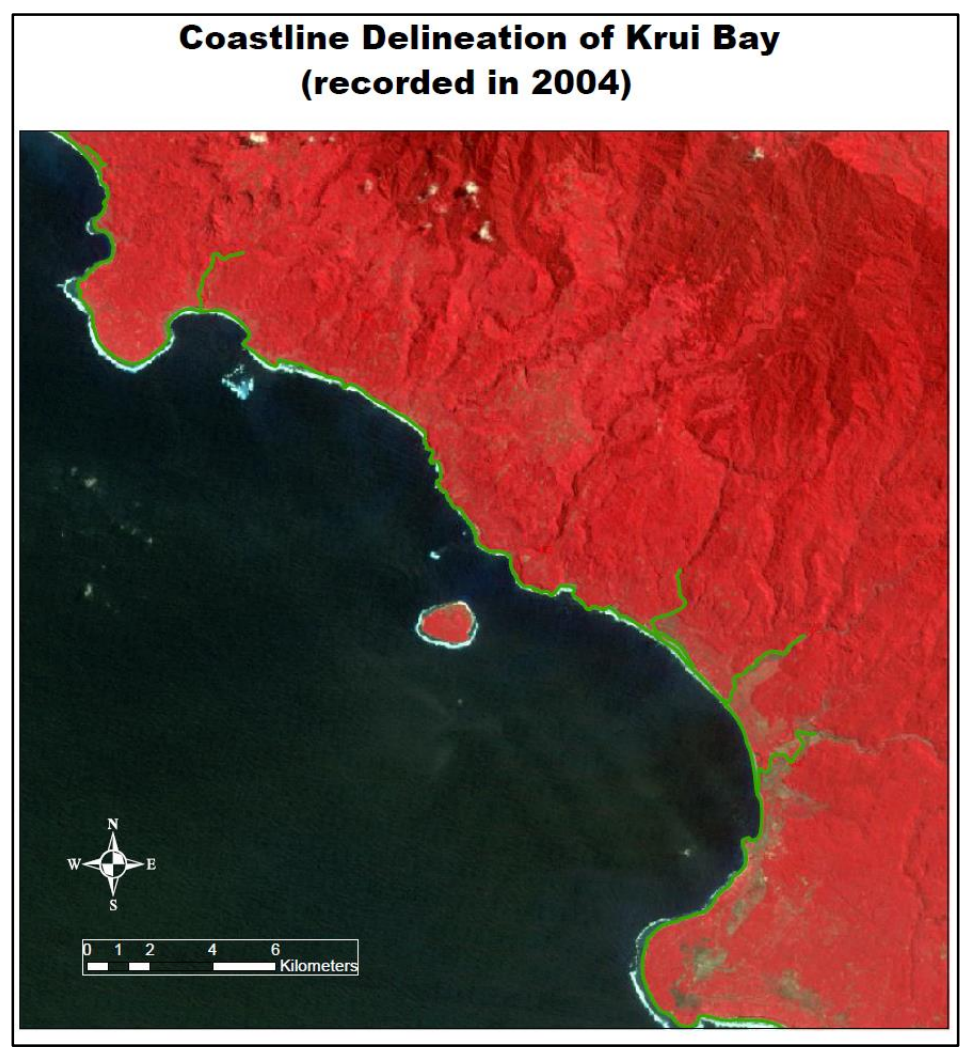

Figure 1. Delineation of Teluk Krui Shoreline in 2004

Measurement of shoreline change is needed to be able to draw conclusions quantitatively. The method of measuring shoreline changes by using transect is applied in this study. The distance between transects is 1 kilometer and it is parallel each other (Figure 3). The transect lines help in determining the distance between initial shoreline and the following year which is considered as a shoreline change. 
ICOSITER 2018 Proceeding Journal of Science and Applicative Technology

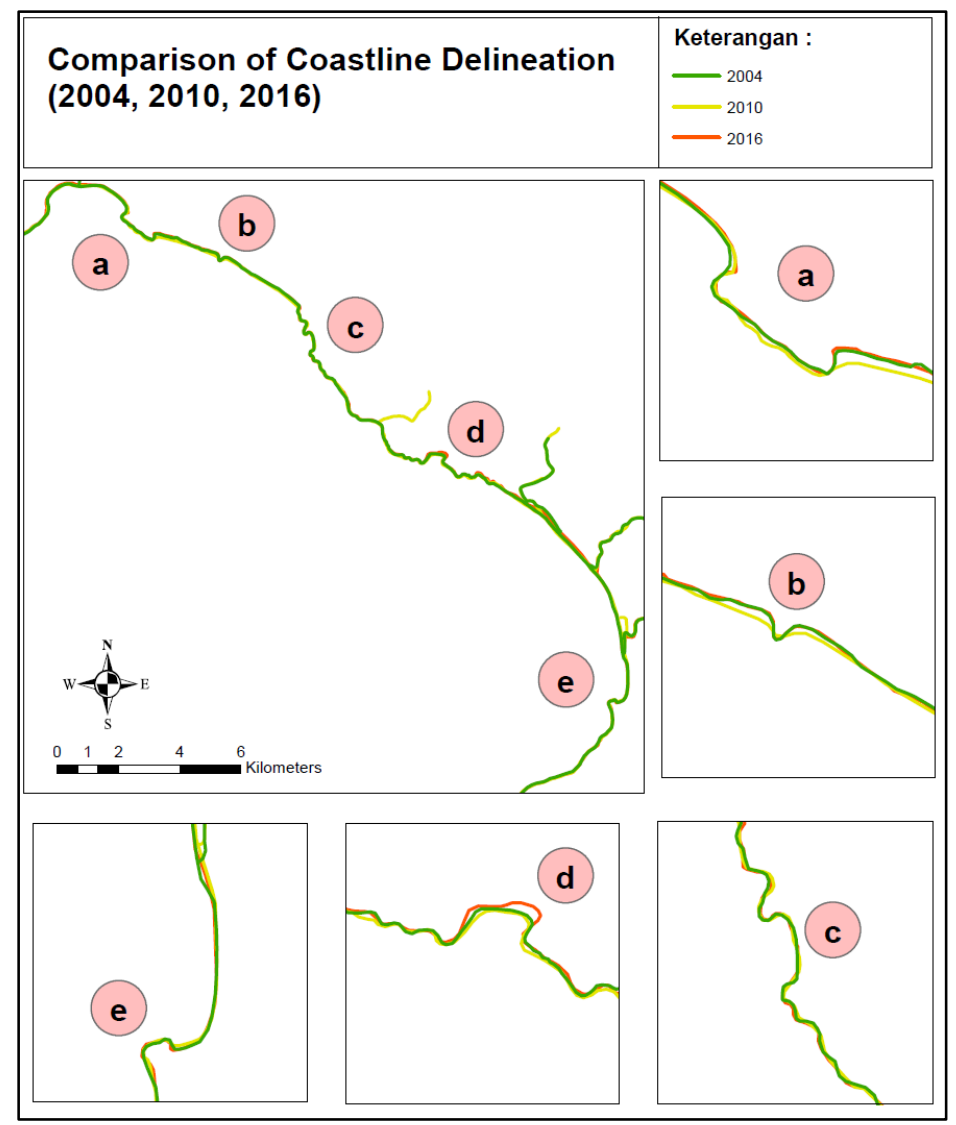

Figure 2. Overlay of shoreline delineation in 2004, 2010, and 2016.

The distance indicating shoreline change is calculated with simple mathematical equations, that is

$$
d=\sqrt{\Delta X^{2}+\Delta Y^{2}}
$$

where $\Delta X=X_{2}-X_{1}$ and $\Delta Y=Y_{2}-Y_{1}$.

The equation is applied for calculating the distance between two points. In the context the shoreline displacement over time, then, $\left(X_{2}, Y_{2}\right)$ can be expressed as a position of $(X, Y)$ in the further time $(n+1)$. Meanwhile, the starting point of the shoreline transect $\left(X_{1}, Y_{1}\right)$ is $(X, Y)$ position in the initial $(n)$. The proposed equation is able to calculating the distance of shoreline change only, because the value is always positive, so it does not explicitly define whether or not a segment has changed the shoreline towards the sea or towards the land. 
ICOSITER 2018 Proceeding Journal of Science and Applicative Technology

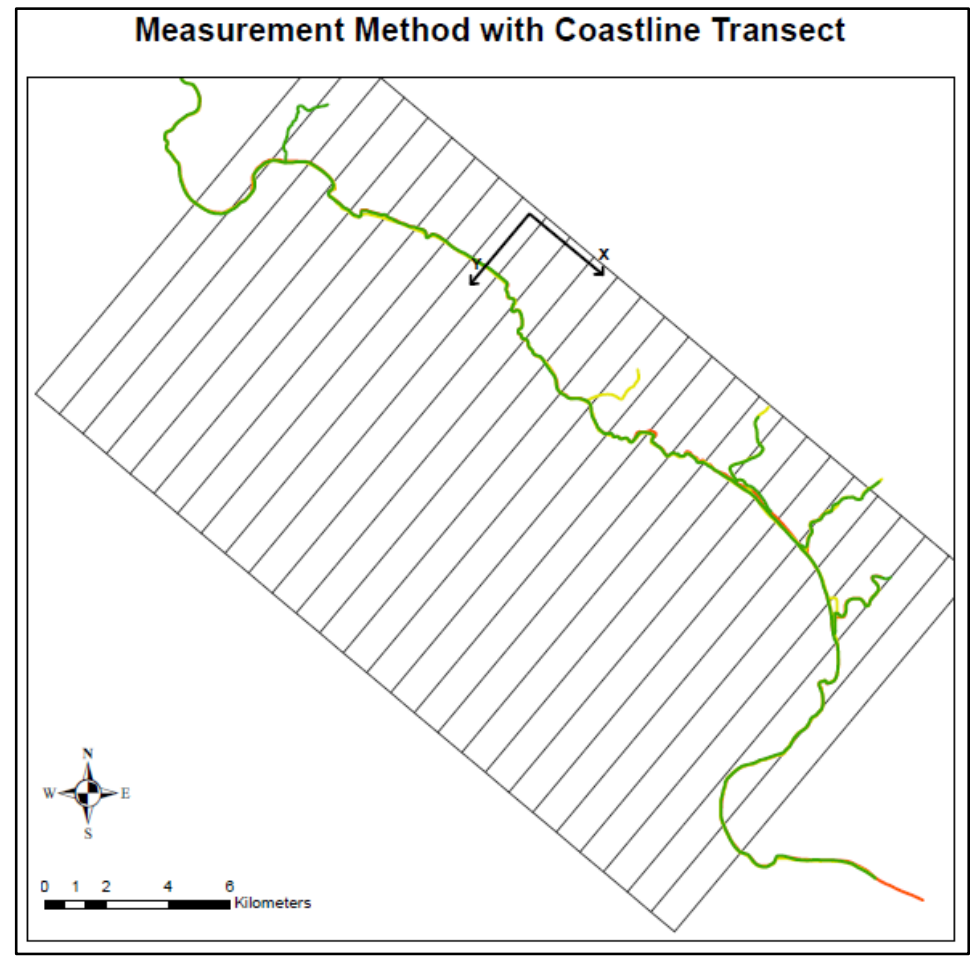

Figure 3. Measurement of shoreline changes by transect method

\section{Results and Discussion}

Analysis of shoreline changes in this study is by comparing changes of shoreline that occured in the period 2004 to 2010 (hereinafter referred to as T1), in the period 2010 to 2016 (hereinafter referred to as T2), and the net changes in the period 2004 to 2016 (called $\Delta \mathrm{T}$ ).

Comparison of shoreline changes T1 with T2 (Figure 4) shows that the process of abrasion and sedimentation occurs alternately. The increment of shoreline occurs at transect 5 to transect 10 with an average of 54 meters, but in T2 there is a decrement of shoreline with an average of 49 meters. Similar phenomena occur at transect 16 to transect 18; transect 20 to transect 22; as well transect 27 to transect 28 where the shoreline increase occur at T1 (respectively, the average of shoreline increment is 57 meters, 33 meters and 12 meters) while the shoreline reduction occurs at T2 (respectively, the average of shoreline decrement is 57 meters, 87 meters and 8 meters). Vice versa at the transect 24 to 26 , the shoreline T1 decrease by an average of 27 meters but on the T2, it increase by an average of 23 meters. Shoreline changes always occur, but the changes are not always increasing or decreasing all the times. The process is very dependent on meteorological and oceanographic conditions that occur within a certain period. 
ICOSITER 2018 Proceeding Journal of Science and Applicative Technology

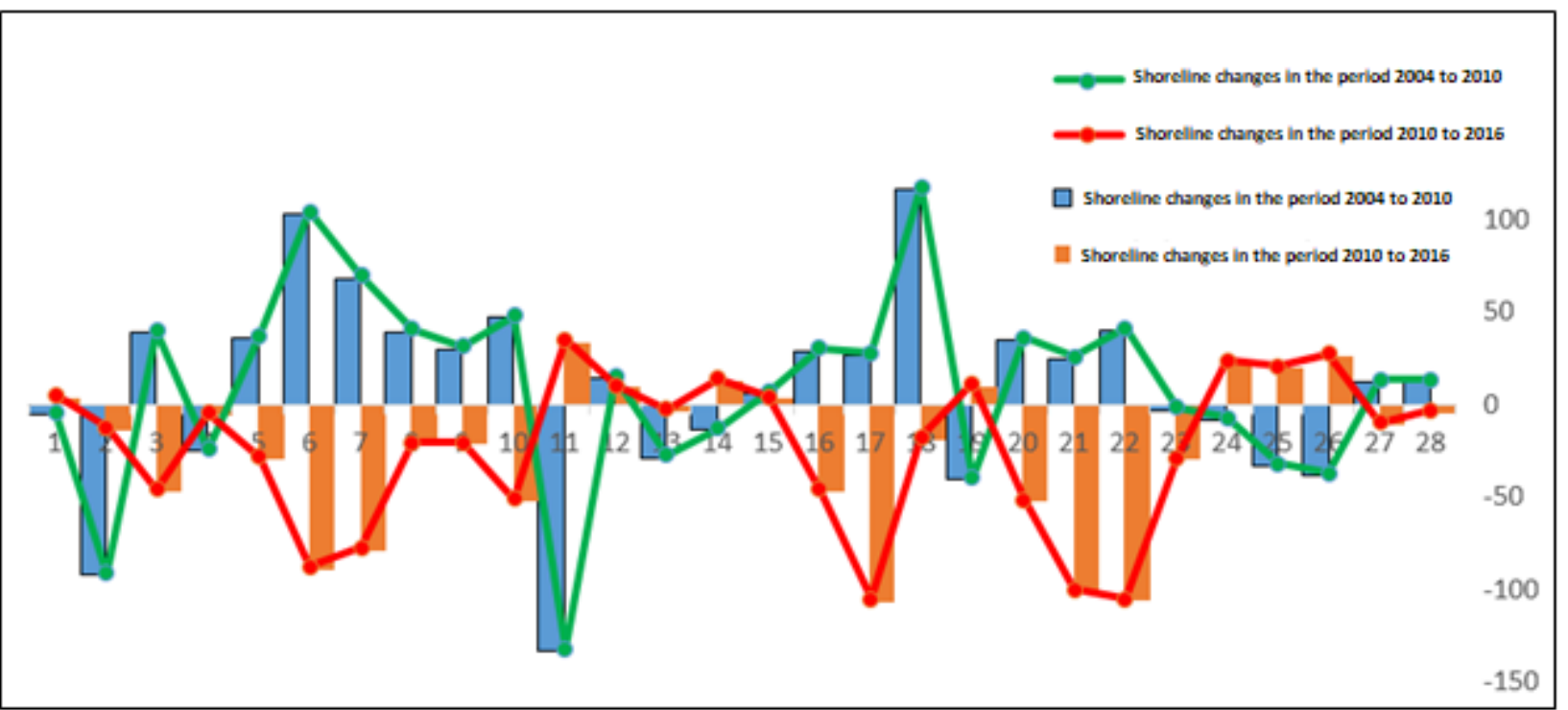

Figure 4. Comparison of shoreline changes between $\mathrm{T} 1$ and $\mathrm{T} 2$

Figure 5 shows that decreasing of shoreline at transect 2 (as long as 92 meters) and transect 11 (as long as 133 meters) have occurred from T1. Increasing of shoreline at transect 5 to 10 that has occurred in T1 tends to decrease in T2 and thus, approaches the initial shoreline position in 2004. Meanwhile, the increasing of shoreline at transect 16 to transect 17 and transect 20 to 22 that had occurred in T1 then experienced a large reduction of shoreline as long as 80 meters from the initial shoreline position in 2004.

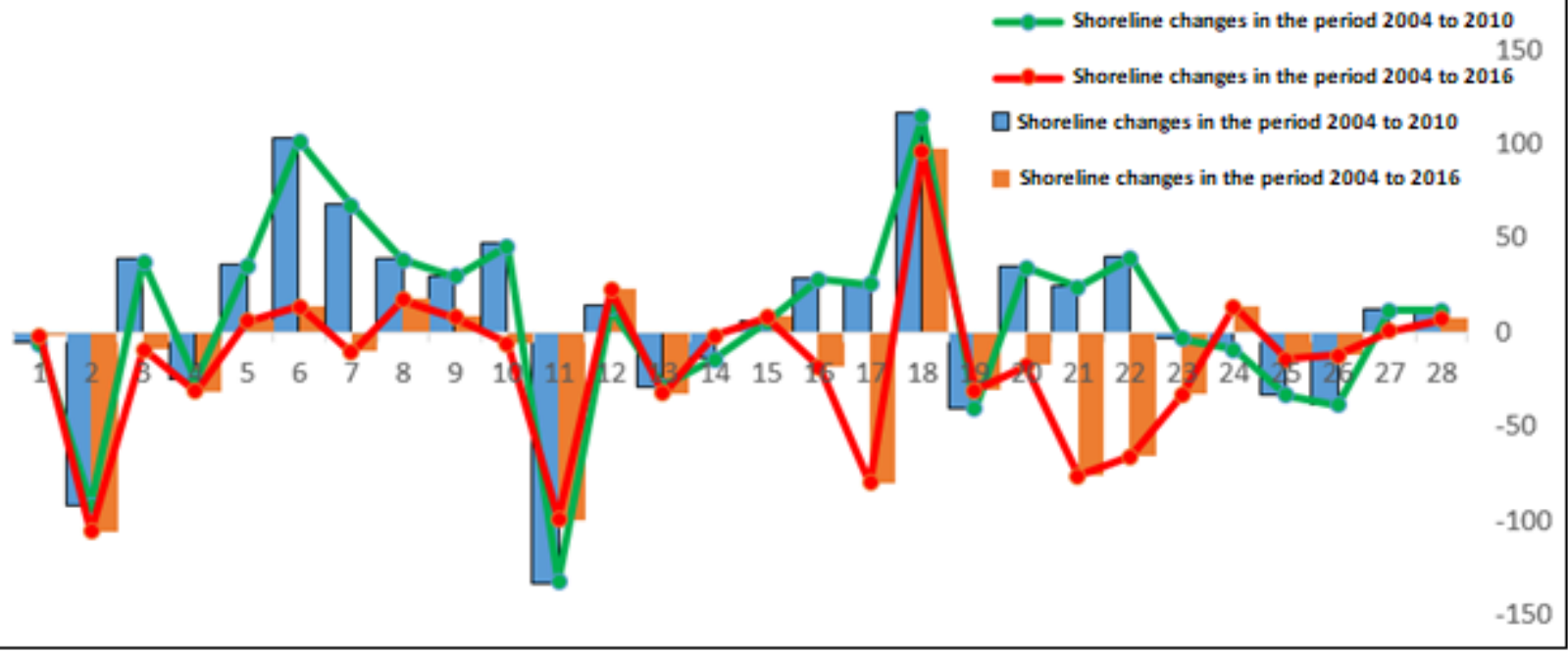

Figure 5. Comparison of shoreline changes between $\mathrm{T} 1$ and $\Delta \mathrm{T}$ 
ICOSITER 2018 Proceeding Journal of Science and Applicative Technology

\section{Conclusion}

The average of shoreline change towards land (abrasion) that occurred in the period of 2004 to 2016 is 35,8 meters with the furthest abrasion location at transect 2 (106,1 meters); transect 11 (99,4 meters); transect 17 (80 meters), and transect 21 (76,5 meters). Meanwhile, the average of shoreline change towards the sea is 19,86 meters with the location of furthest sedimentation at transect 18 ( 97,4 meters).

\section{REFERENCE}

Kasim, F. 2012. Pendekatan beberapa metode dalam monitoring perubahan garis pantai menggunakan dataset penginderaan jauh landsat dan SIG. Jurnal Ilmiah Agropolitan Vol. 5 No. 1, April 2012 : 620 635.

Suwargana, N. 2013. Resolusi spasial, temporal dan spektral pada citra satelit Landsat, SPOT dan IKONOS. Jurnal Ilmiah Widya Vol. 1 No. 2, Juli 2013 : 167 - 174

Tarigan, M.S. 2007. Perubahan garis pantai di wilayah pesisir perairan Cisadane, Provinsi Banten. Makara, Sains Vol. 11 No. 1, April 2007 : 49 - 55

Winarso, G., Budhiman, S., dan Judijanto. 2001. The potential application of remote sensing data for coastal study. Proceeding on $22^{\text {nd }}$ Asian Conference on Remote Sensing, CRISP NUS and Asian Association on Remote Sensing. Singapore. 